\title{
Information Technology Implementation and Operational Efficiency
}

\author{
Jin Kyung Kwak* \\ Department of Business Administration, Ewha Womans University
}

(Received: September 1, 2013 / Revised: September 28, 2013 / Accepted: September 30, 2013)

\begin{abstract}
In this paper, we analyze the relationship between implementation of information technology and inventory turnover as a measure of operational efficiency. We build a regression model including a dummy variable that indicates whether a firm has been nominated for being good at implementing information technology. By using publicly available data, we have conducted an extensive empirical analysis and found that firms' using information technology is not likely to affect inventory turnover significantly. This result implies that we have to take careful consideration in adapting information technology.
\end{abstract}

Keywords: Information Technology, Operational Efficiency, Inventory Turnover, Econometric Analysis

* Corresponding Author, E-mail: jkkwak@ewha.ac.kr

\section{INTRODUCTION}

In early 2000 s, information technology was popularly adapted in many businesses not only limited to high-tech industry. Existing major companies were also interested in using information systems such as electronic data interchange (EDI), enterprise resource planning (ERP), etc. Despite its importance, there have been few studies about whether the investment on these information systems actually improves operational efficiency. If the system did not work properly, information delay due to the failure of technology affects the long run average inventory cost (Kim, 2006; Kim, 2010). By empirically searching for the relationship between the use of information technology (IT hereafter) and inventory turnover as a measure of operational efficiency, this paper aims to discuss the considerations when adapting information systems.

It is common to use inventory turnover as an operational performance measure (Dehning et al., 2007; Demeter, 2003; Gaur et al., 2005; Vastag and Whybark, 2005). In particular, to develop the model in this paper, we refer to Gaur et al. (2005) examining the correlation of inventory turnover with gross margin, capital inten- sity, and sales surprise. Several papers empirically study what affects inventory turnover: Zhu et al. (2002) has found a significant relation between e-commerce capability and inventory turnover; and Demeter (2003) has observed that the existence of a manufacturing strategy does not affect inventory turnover. Besides, Byrd and Davidson (2003) and Vickery et al. (2003) have reported that IT investments in supply chain management can improve firm performance.

These studies are mostly based on a survey, conceptual analysis, or case studies. Dehning et al. (2007), on the other hand, explored the impact of IT-based supply chain management systems on financial performances by using externally reported, publicly available data, like we do. While they have examined the changes in financial measures pre and post implementation of such IT-based systems, we observe whether there is a significant difference between the inventory turnover of the recognized IT-implementing firms and that of other firms. There have been some recent papers about the impact of IT on firms' performance, for specific industries in certain countries (Bazaee, 2010; Choe, 2006; GuLES et al., 2012; Liang et al., 2010; Ray et al., 2013; Zhaneta and Liljana, 2012). Whereas those papers have 
focused on whether IT investment affects the performance, our focus is to observe whether there is a significant difference between the companies that are recognized with IT excellence and those that are not, in terms of operational efficiency.

As it is usually very costly to implement information systems such as ERP (Vastag and Whybark, 2005), it is worthwhile to discuss the effectiveness of IT implementation with regard to operational efficiency. This paper suggests careful investment in IT by empirically analyzing the correlation between IT recognition and inventory turnover with extensive public data.

\section{DATA AND MODEL}

The companies that effectively implement IT systems have been identified by Information Week 500 . Information Week is a weekly magazine and has nominated the nation's most innovative IT organizations. The Information Week 500 project has identified the 500 rankings annually, based on surveys. Only companies with at least $\$ 500$ million in annual revenue are invited to participate in the project. Information Week claims that 500 winners are continually striving for greater efficiency and more streamlined business processes.

Table 1. Information Week 500 IT Spent (Dollars in Million)

\begin{tabular}{|c|c|c|c|c|c|}
\hline Year & 2001 & 2002 & 2003 & 2004 & 2005 \\
\hline $\begin{array}{c}\text { Average } \\
\text { company } \\
\text { revenue }\end{array}$ & $\$ 12,471$ & $\$ 9,427$ & $\$ 9,652$ & $\$ 9,087$ & $\$ 9,776$ \\
\hline $\begin{array}{c}\text { Average } \\
\text { IT dollars } \\
\text { spent }\end{array}$ & $\$ 484$ & $\$ 320$ & $\$ 353$ & $\$ 334$ & $\$ 293$ \\
\hline $\begin{array}{c}\text { Average IT } \\
\text { budget as a } \% \\
\text { of revenue }\end{array}$ & $3.88 \%$ & $3.39 \%$ & $3.66 \%$ & $3.68 \%$ & $3.00 \%$ \\
\hline
\end{tabular}

These companies have spent more than $3 \%$ of their revenue on IT each year (Table 1). The question is whether these investments are actually worthy in an operational aspect. To test if there is a significant discrepancy between the performance measure of the companies in the Information Week 500 rankings and that of the companies not in the rankings, we use regression model of which the dependent variable is inventory turnover as a measure of operational efficiency. Inventory turnover represents the number of times the average inventory of a firm is sold over a given time period (typically a year), which is an indicator of a firm's operational efficiency along its supply chain (Zhu, 2004).

In this study, we use logIT (log of inventory turnover) as a dependent variable that is developed in Gaur et al. (2005) in which a log-linear relationship is suggested between variables. We use the same variables from Gaur et al. (2005)- $\log G M$ (log of gross margin), $\log$ CI (log of capital intensity), and $\log S \mathrm{~S}$ (log of sales surprise)-and add some more independent variables. We add a dummy variable Rank that attains the value of 1 if a firm is in the Information Week 500 rankings and gets 0 otherwise. We also include additional variable logSize (log of Size) to consider the firm's size affecting the inventory turnover measure. To account for size differences among firms, the ratio of cost of goods sold divided by number of employees is used as in Zhu (2004).

We have obtained the financial data from Standard and Poor's Compustat database using the Wharton Research Data Services (WRDS). Each objective company is recognized by its SPC permanent number, GVKEY. We use the data of active companies only and the year periods are from 2000 to 2005, as IT systems were actively adapted in those times and in later 2000s there might be an effect of economic downturn in the United States. The number of observations read is 55764 and the number of observations actually used is 23332 . Among the companies, we categorize the firms according to whether they are nominated for Information Week 500 rankings. Table 2 shows the number of companies used for Rank $=1$ each year in the data.

Table 2. Number of Companies used for Rank $=1$ Each Year

\begin{tabular}{|c|c|}
\hline Year & \# firms used \\
\hline 2000 & 375 \\
\hline 2001 & 373 \\
\hline 2002 & 389 \\
\hline 2003 & 382 \\
\hline 2004 & 376 \\
\hline 2005 & 351 \\
\hline
\end{tabular}

The model in this study is developed as follows:

$$
\begin{aligned}
\operatorname{logIT} \mathrm{Tit}_{\mathrm{it}}= & \mathrm{b}_{0}+\mathrm{b}_{1} \times \text { Rank }_{\mathrm{it}}+\mathrm{b}_{2} \times \log \mathrm{GM}_{\mathrm{it}}+\mathrm{b}_{3} \times \log \mathrm{CI}_{\mathrm{it}} \\
& +\mathrm{b}_{4} \times \operatorname{logSS_{it}}+\mathrm{b}_{5} \times \log \operatorname{Size}_{\mathrm{it}} .
\end{aligned}
$$

If we let $\mathrm{CGS}_{\text {it }}$ denote cost of goods sold of firm $\mathrm{i}$ in year $t, I n v_{i t}$ denote average inventory, GFA $A_{i t}$ denote gross fixed assets, $\mathrm{S}_{\text {it }}$ denote net sales and $\mathrm{Emp}_{\mathrm{it}}$ donote the number of employees, then our variables are computed as follows:

$$
\begin{aligned}
\mathrm{IT}_{\mathrm{it}} & =\frac{\mathrm{CGS}_{\mathrm{it}}}{\mathrm{Inv}_{\mathrm{it}}} . \\
\mathrm{GM}_{\mathrm{it}} & =\frac{\mathrm{S}_{\mathrm{it}}-\mathrm{CGS}_{\mathrm{it}}}{\mathrm{S}_{\mathrm{it}}} . \\
\mathrm{CI}_{\mathrm{it}} & =\frac{\mathrm{GFA}_{\mathrm{it}}}{\operatorname{Inv}_{\mathrm{it}}+\mathrm{GFA}_{\mathrm{it}}} . \\
\mathrm{SS}_{\mathrm{it}} & =\frac{\mathrm{S}_{\mathrm{it}}}{\text { SalesForecast }_{\mathrm{it}}}
\end{aligned}
$$


Where

$$
\begin{aligned}
& \text { SalesForecast }_{i t}=\mathrm{L}_{\mathrm{i}, t-1}+\mathrm{T}_{\mathrm{i}, t-1}, \\
& \mathrm{~L}_{\mathrm{it}}=0.75 \times \mathrm{S}_{\mathrm{it}}+0.25 \times\left(\mathrm{L}_{\mathrm{i}, t-1}+\mathrm{T}_{\mathrm{i}, t-1}\right), \\
& \mathrm{T}_{\mathrm{it}}=0.75 \times\left(\mathrm{L}_{\mathrm{it}}-\mathrm{L}_{\mathrm{i}, \mathrm{t}-1}\right)+0.25 \times \mathrm{T}_{\mathrm{i}, t-1} . \\
& \text { Size }_{\mathrm{it}}=\frac{\mathrm{CGS}_{\mathrm{it}}}{\mathrm{Emp}_{\mathrm{it}}} .
\end{aligned}
$$

Table 3. Descriptive Statistics for Variables

\begin{tabular}{|c|c|c|c|c|c|}
\hline Variable & $\mathrm{N}$ & Mean & Std Dev & Min & Max \\
\hline $\log \mathrm{TT}$ & 30598 & 2.0208 & 1.4731 & -5.3568 & 10.4762 \\
Rank & 55764 & 0.0403 & 0.1966 & 0 & 1 \\
$\operatorname{logGM}$ & 39704 & -1.0497 & 0.7056 & -9.1667 & 5.8811 \\
$\log \mathrm{CI}$ & 37404 & -0.2633 & 0.4680 & -5.9054 & 0 \\
$\operatorname{logSS}$ & 39766 & 0.0398 & 0.6537 & -9.2308 & 9.4760 \\
$\operatorname{logSize}$ & 38861 & 4.8128 & 1.1725 & -5.1648 & 11.4620 \\
\hline
\end{tabular}

The explanation of gross margin, capital intensity and sales surprise is detailed in Gaur et al. (2005). The number of observations, mean, standard deviation, minimum value, and maximum value of each independent variable in our model are described in Table 3. The VIF (variation inflation factor) of each variable (Table 4) shows no serious multicollinearity problem.

Table 4. Variation Inflation Factor of Each Variable

\begin{tabular}{|c|c|}
\hline Variable & VIF \\
\hline Rank & 1.00845 \\
$\operatorname{logGM}$ & 1.22823 \\
$\log C \mathrm{I}$ & 1.02527 \\
$\operatorname{logSS}$ & 1.00258 \\
$\operatorname{logSize}$ & 1.26043 \\
\hline
\end{tabular}

\section{ANALYSIS}

Due to the existence of heteroscedasticity (Table 5), we have decided to employ a weighted least squares (WLS) regression. By plotting the relationship between residuals squared and each variable (See Appendix), we have found that $\log$ Size has the most similar pattern with the plot of residuals squared versus logIT.

Table 5. Tests for Heteroscedasticity

\begin{tabular}{|c|c|c|c|}
\hline Test & $\begin{array}{c}\text { Chi-square } \\
\text { statistic }\end{array}$ & $\begin{array}{c}\text { Degrees of } \\
\text { freedom }\end{array}$ & $\begin{array}{c}\text { Pr }>\text { Chi- } \\
\text { square }\end{array}$ \\
\hline White's & 2909 & 19 & $<.0001$ \\
Breush-Pagan & 521.2 & 5 & $<.0001$ \\
\hline
\end{tabular}

Table 6 summarizes the results from the WLS regression with a weight $1 /$ sqrt (logSize).
Table 6. Parameter Estimates of WLS with logSize

\begin{tabular}{|c|c|c|c|c|}
\hline Variable & $\begin{array}{c}\text { Parameter } \\
\text { Estimate }\end{array}$ & $\begin{array}{c}\text { Standard } \\
\text { Error }\end{array}$ & $\mathrm{t}$ value & $\operatorname{Pr}>|\mathrm{t}|$ \\
\hline Intercept & 0.72100 & 0.02856 & 25.24 & $<.0001$ \\
Rank & -0.03171 & 0.03148 & -1.01 & 0.3137 \\
$\operatorname{logGM}$ & -0.59483 & 0.01253 & -47.48 & $<.0001$ \\
$\log \mathrm{CI}$ & 1.52617 & 0.01557 & 98.04 & $<.0001$ \\
$\operatorname{logSS}$ & 0.04592 & 0.01203 & 3.82 & 0.0001 \\
$\operatorname{logSize}$ & 0.23373 & 0.00687 & 34.02 & $<.0001$ \\
\hline
\end{tabular}

Though the measures of gross margin, capital intensity, sales surprise and size are actually related to the inventory turnover, we were not able to find a significant correlation between Rank and inventory turnover. Therefore, we cannot claim that the companies that are recognized as being good at implementing IT are more efficient in terms of inventory turnover.

By considering model selection criteria as shown in Table 7, we can observe that our model is the second best according to the values of AIC (Akaike Information Criteria) and BIC (Bayesian Information Criteria). The best model contains four independent variables and excludes the dummy variable Rank, which makes sense because we were not able to find a significant relationship between the Rank and the logIT. Still, the AIC and BIC values of our model are very close to those of the best possible model so that we could determine that the model and the data we used in this study are appropriate

\begin{tabular}{|c|c|c|}
\hline Variables in the Model & AIC & BIC \\
\hline $\log \mathrm{GM}, \log \mathrm{CI}, \log \mathrm{SS}, \log$ Size & 2042.8736 & 2044.8758 \\
\hline $\begin{array}{l}\text { Rank, } \log \mathrm{GM}, \log \mathrm{CI}, \log \mathrm{SS} \text {, } \\
\operatorname{logSize}\end{array}$ & 2044.0174 & 2046.0205 \\
\hline $\log \mathrm{GM}, \log \mathrm{CI}, \log$ Size & 2051.4814 & 2053.4795 \\
\hline Rank, $\log \mathrm{GM}, \log \mathrm{CI}, \log$ Size & 2052.5033 & 2054.5013 \\
\hline Rank, $\log \mathrm{GM}, \log \mathrm{CI}, \log \mathrm{SS}$ & 2795.2518 & 2796.9346 \\
\hline
\end{tabular}
to analyze the relationship between the use of IT and operational efficiency of firms.

Table 7. Model Selection Criteria

Table 8. Prais-Winsten Estimates (Correction for FirstOrder Serial Correlation)

\begin{tabular}{|c|c|c|c|c|}
\hline Variable & $\begin{array}{c}\text { Parameter } \\
\text { Estimate }\end{array}$ & $\begin{array}{c}\text { Standard } \\
\text { Error }\end{array}$ & $\mathrm{t}$ value & $\operatorname{Pr}>|\mathrm{t}|$ \\
\hline Intercept & 1.5735 & 0.0205 & 76.90 & $<.0001$ \\
Rank & -0.0109 & 0.0158 & -0.69 & 0.4900 \\
$\log \mathrm{GM}$ & -0.1755 & 0.006809 & -25.78 & $<.0001$ \\
$\log \mathrm{CI}$ & 0.5065 & 0.009230 & 54.87 & $<.0001$ \\
$\operatorname{logSS}$ & 0.0174 & 0.007622 & 2.28 & 0.0228 \\
$\operatorname{logSize}$ & 0.0875 & 0.004291 & 20.39 & $<.0001$ \\
\hline
\end{tabular}


As we have identified a strong positive autocorrelation in a six-year time series (Durbin-Whatson D: 0.645, the Lagrange multiplier value of Godfrey's serial correlation test: 43.13), there is a need to resolve this issue. When we correct for the first-order serial correlation (Table 8), we still get the robust result of an insignificant relation between Rank and logIT.

\section{DISCUSSION AND CONCLUSION}

By conducting the extensive empirical analysis, we have found the irrelevance of IT rankings and operational efficiency. In other words, being assessed as an innovative IT user does not mean being operationally efficient. This result somewhat contradicts our intuition that the companies in the rankings of Information Week 500 will have better inventory turnover performance. On the other hand, it is not so surprising because, frequently, the failure of firms' IT projects have been reported. It is stated that more than $70 \%$ of all IT-related projects fail to meet their objectives (Lewis, 2001). In particular, from in-depth literature review (1997-2009), Momoh et al. (2010) summarized the nine factors that are critical for ERP implementation failures.

If we are aware that IT might fail and can identify the reasons of the possible failure, we are able to be more careful in investing in IT projects. How to deal with each critical factor will be an important subject for future research. Crucial contribution of this paper lies on verifying empirically that there is no direct correlation between IT execution and operational efficiency so that we can think of what to consider for successful IT implementation before huge investment.

\section{ACKNOWLEDGEMENT}

This work was supported by Ewha Womans University Research Grant of 2012.

\section{REFERENCES}

Bazaee, G. I., "Effects of Information Technology Investment on Organizational Performance in India and Iran: An Empirical Study," Int. J of Management 27, 1 (2010), 76-82.

Byrd, T. A. and N. W. Davidson, "Examining possible antecedents of IT impact on the supply chain and its effect on firm performance," Information and Management 41 (2003), 243-255.

Choe, J., "The Cultural Effects on Information Characteristics of Accounting Information Systems," Int. J of Management Science 12, 1 (2006), 35-64.

Dehning, B., V. J. Richardson, and R. W. Zmud, "The financial performance effects of IT-based supply chain management systems in manufacturing firms," Journal of Operations Management 25 (2007), 806824.

Demeter, K., "Manufacturing strategy and competitiveness," Int. J. of Production Economics 81/82 (2003), 205-213.

Gaur, V., M. Fisher, and A. Raman, "An econometric analysis of inventory turnover performance in retail services," Management Science 51 (2005), 181-194.

GuLES, H. K., V. caGLAYAN, and M. BEDuK, "The Strategic Impact of Information Technologies on Supply Chain and Business Performance," J of Business Research-Turk 4, 1 (2012), 183-200.

Kim, H., "The Cost Impact of Information Delay in a Supply Chain," Int. J of Management Science (2006), $1-34$,

Kim, H., "Numerical Studies on the Cost Impact of Incorrect Assumptions and Information Delay in a Supply Chain," Int. J of Management Science 16, 3 (2010), 1-20.

Lewis, B., "The 70-percent failure," InfoWorld 23 (2001), 50.

Liang, T., J. You, and C. Liu, "A resource-based perspective on information technology and firm performance: a meta analysis," Industrial Management and Data Systems 110, 8 (2010), 1138-1158.

Momoh, A., R. Roy, and E. Shehab, "Challenges in enterprise resource planning implementation: stateof-the-art," Business Process Management Journal 16, 4 (2010), 537-565.

Ray, G., L. Xue, and J. B. Barney, "Impact of information technology capital on firm scope and performance: the role of asset characteristics," Academy of Management Journal 56, 4 (2013), 1125-1147.

Scapens, R., M. Jazayeri, and J. Scapens, "SAP: integrated information systems and the implications for management accountant," Management Accounting (British) 76, 8 (1998), 46-49.

Vastag, G. and D. C. Whybark, "Inventory management: Is there a knock-on effect?," Int. J of Production Economics 93/94 (2005), 129-183.

Vickery, S. K., J. Jayaram, C. Droge, and R. Calantone, "The effects of an integrative supply chain strategy on customer service and financial performance: an analysis of direct versus indirect relationships," Journal of Operations Management 21 (2003), 523539.

Zhaneta, N. and E. Liljana, "The effects of relationship between information technology and firm innovation on firm performance: the case of Albania," Int. J of Management Cases 14, 1 (2012), 235-246. 
Zhu, K. and K. L. Kraemer, "e-commerce metrics for net-enhanced organizations: assessing the value of e-commerce to firm performance in the manufacturing sector," Information Systems Research 13 (2002), 275-295.
Zhu, K., "The complementarity of information technology infrastructure and e-commerce capability: a resource-based assessment of their business value," Journal of Management Information Systems 21 (2004), 167-202. 


\section{APPENDIX}

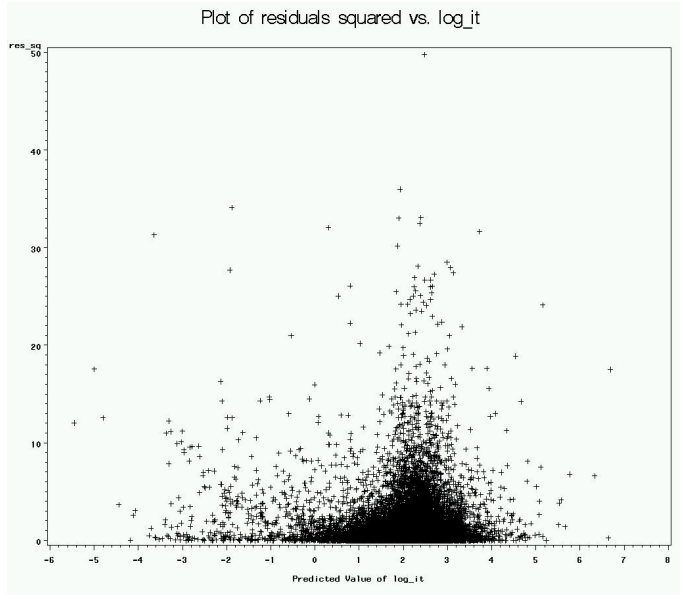

Figure 1. Plot of Residuals Squared vs. $\log I T$

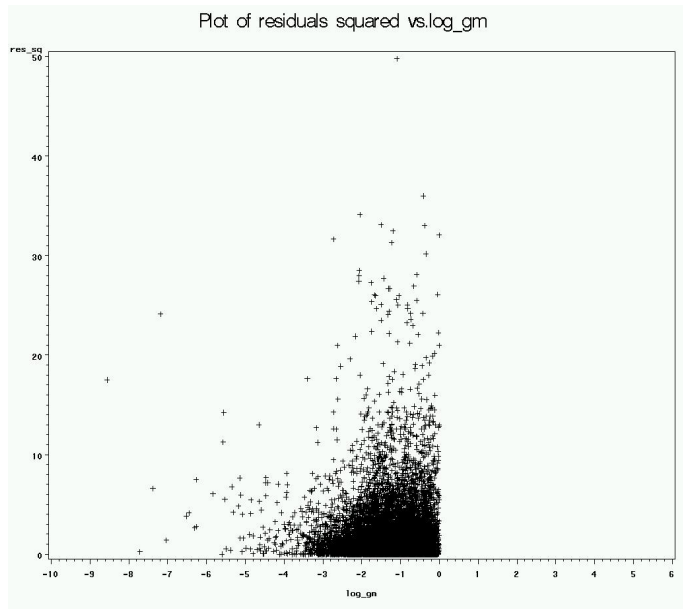

Figure 2. Plot of Residuals Squared vs. $\log G M$

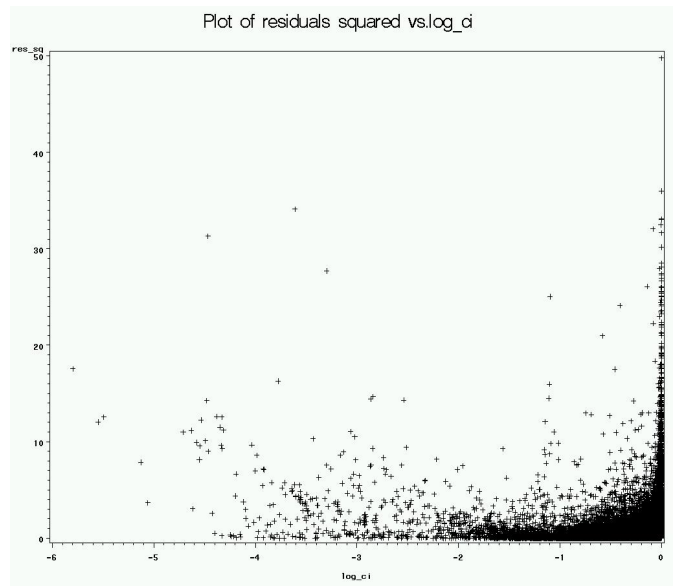

Figure 3. Plot of Residuals Squared vs. $\log \mathrm{CI}$

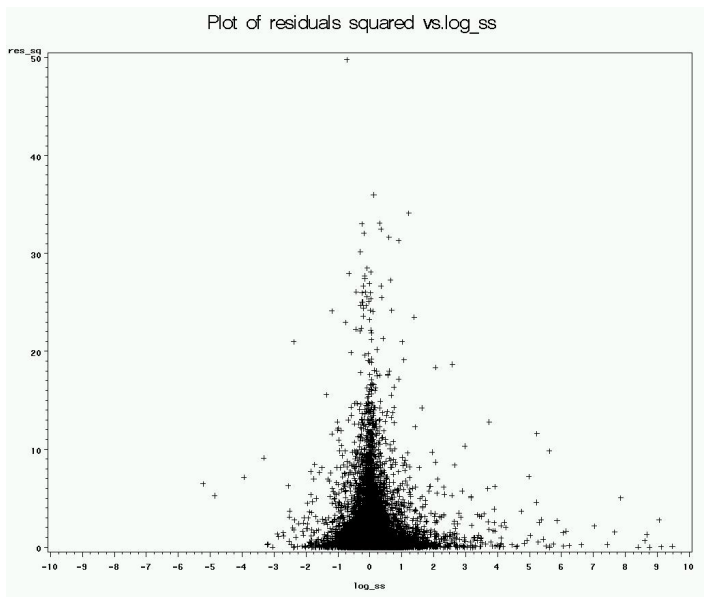

Figure 4. Plot of Residuals Squared vs. $\operatorname{logSS}$

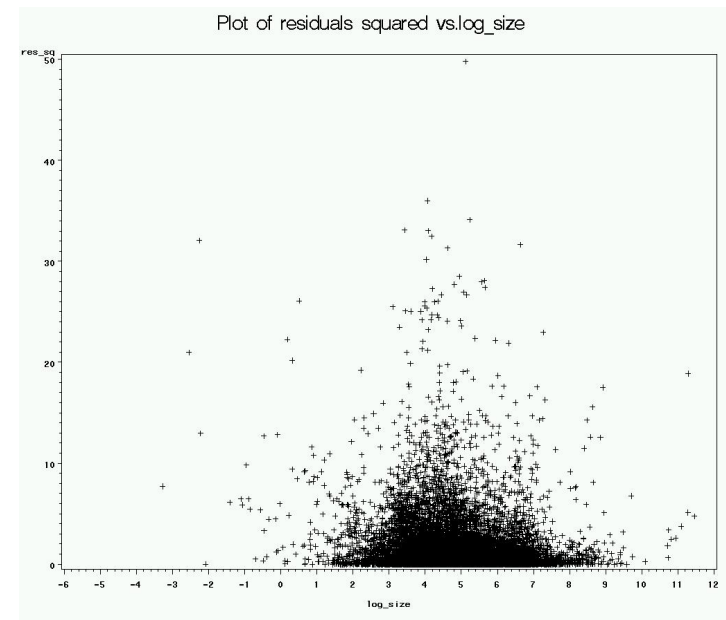

Figure 5. Plot of residuals squared vs. $\operatorname{logSize}$ 